\title{
The Increase of Arthropods Biodiversity in Paddy Field Ecosystem Managed by Using Integrated Pest Management at South Borneo
}

\author{
Samharinto ${ }^{1}{ }^{2}$, A. Latief Abadi ${ }^{2}$, Bambang Tri Rahardjo² ${ }^{2}$ and Hakimah Halim ${ }^{1}$ \\ ${ }^{1}$ Faculty of Agriculture, Lambung Mangkurat University, Banjarbaru, Indonesia \\ ${ }^{2}$ Postgraduate Program, Faculty of Agriculture, Brawijaya University, Malang, Indonesia
}

\begin{abstract}
We have studied the arthropods biodiversity in two paddy field ecosystems, namely, paddy field ecosystem using Integrated Pest Management (IPM) system and non-IPM paddy field ecosystem. This study was conducted from April 2011 - November 2011 in three locations, that is, Pasar Kamis village and Sungai Rangas village in Banjar regency, and Guntung Payung village in Banjarbaru city, South Borneo Province. In this study, we used insect nets, yellow sticky traps, light trap and pitfall trap to get the sample or catch the arthropods in one period of planting season. The arthropods caught were then classified into some classes: pest (herbivore), natural enemy (parasitoid and predator), and other arthropods. After that, the Species Diversity Index was determined using its Shannon-Wiener Index $\left(H^{\prime}\right)$, Evenness (e), Species Richness (R), and Species Similarity Index (IS). The sum of arthropods which have the characteristic of pest and parasitoid were higher in the IPM paddy fields than in the non-IPM paddy fields, and the sum of other arthropods were the same. The highest $\mathrm{H}^{\prime}$ and e values were in the IPM paddy field in Pasar Kamis village. The IS value for each three locations were 77.5\% in Pasar Kamis village, $93.42 \%$ in Guntung Payung village, and $78.76 \%$ in Sungai Rangas village.
\end{abstract}

Keywords: diversity, arthropods, ecosystem, and SLPHT

\section{INTRODUCTION}

In farming practice, farmers often use pesticide to control pest because they do not want to take the risk of losing their yield. The use of pesticide in a large scale will reduce the biodiversity, especially that of arthropods and other natural microorganisms in agro ecosystem. Many of the arthropods are useful for controlling plant pests naturally or as biological agent/natural enemy in controlling the pest abundance. According to Flint and Bosch (1990), the presence of insect pest and natural enemy in the ecosystem will contribute to the environment stability because they also build food webs)[1]. The more complex the food webs, the more stable the ecosystem will be.

Farmer Field School of Integrated Pest Management / FFS of IPM (Sekolah Lapangan Pengendalian Hama Terpadu/SLPHT) is an adult education whose participants are farmer group

\footnotetext{
*Corresponding address:

Samharinto

Postgraduate Program,

Faculty of Agriculture,

Brawijaya University,

Jl. Veteran, Malang, Indonesia

samharinto@yahoo.com
}

members[2,3]. The purpose of this education is to empower the farmers to independently take the decision upon agro ecosystem and farming system management based on four integrated pest control principles (IPM), namely, health plant cultivation, keeping and utilizing natural enemies, periodic ecosystem monitoring, and farmers as the IPM expert [4]. By following SLPHT, it is hoped that the farmers will apply the IPM concept in their farming land so that their crops will be better without damaging their farming land ecosystem[4]. The success of the IPM farming applied by SLPHT alumni is examined through the arthropods biodiversity in their paddy fields. Yet, the arthropods biodiversity in the IPM paddy fields of SLPHT alumni and non IPM paddy fields in Borneo province is unknown or not yet examined. Therefore, this study is aimed to find out the arthropods biodiversity in two paddy field ecosystems, that is, the IPM paddy field ecosystem worked by SLPHT alumni and non IPM paddy field ecosystem worked by general farmers. The different biodiversity of the arthropods in the IPM and non IPM paddy field ecosystems is used as a former data in managing agro ecosystem in South Borneo Province. 


\section{MATERIALS AND METHODS}

This study was conducted from April to November 2011 in three villages, namely, Pasar Kamis village and Sungai Rangas village in Banjar regency, and Guntung Payung village in Banjarbaru city, South Borneo Province. To find out the arthropods performance, we catched them using four kinds of trap, that is, insect nets, yellow sticky traps, light trap and pitfall trap. The arthropods capture using three kinds of trap was done since the paddy is \pm 1.5 months until near the harvest time ( \pm 6 months after the planting) with a week of capturing period, except for the pitfall trap which was used since the water in the paddy field started to reduce until near the harvest time. The arthropods caught were then classified into 4 classes: pest (herbivore), parasitoid, predator, and other arthropods. The arthropods identification was done based on identification books of Borror, De Long, and Triplehom (1991); Reisssig, Heinrich, Litsinger, Moody, Fieder, Meww and Barrion (1986) through the family morphologically $[5,6]$. The data was analyzed to determine the Species Diversity Index (H') using Shannon-Wiener Index (Zar, 1984), Species Richness Index (R), Species Evenness Index (e) according to Pielou (1984), and Sorenssen Species Similarity Index (IS) according to Suin (1989) $[7,8,9]$.

\section{RESULTS AND DISCUSSION}

In the three IPM paddy field locations, the sum of arthropods which had the characteristics of pest, parasitoid, and predator were higher than in the non-IPM paddy fields, while the sum of other arthropods in those two ecosystems were the same. The abundance of arthropods which had the characteristic of pest, parasitoid, and predator were also higher in the IPM paddy fields than in the non-IPM paddy fields, except for the sum of predators in Guntung Payung village which was lesser (Table 1) (Figure 1, 2, and 3).

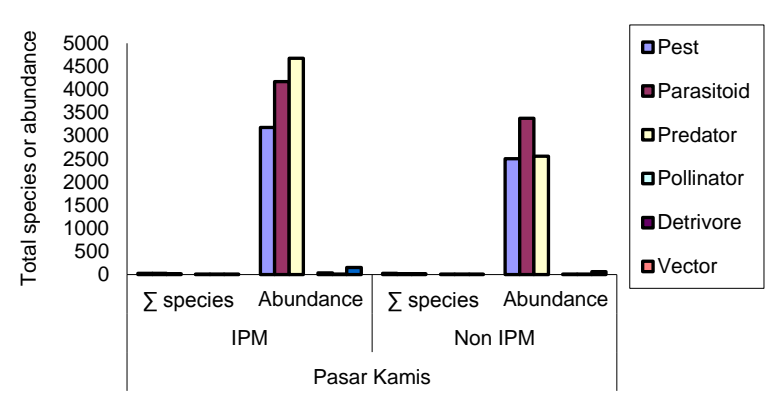

Figure 1. Histogram status, total of species and abundance of arthropods in Pasar Kamis village

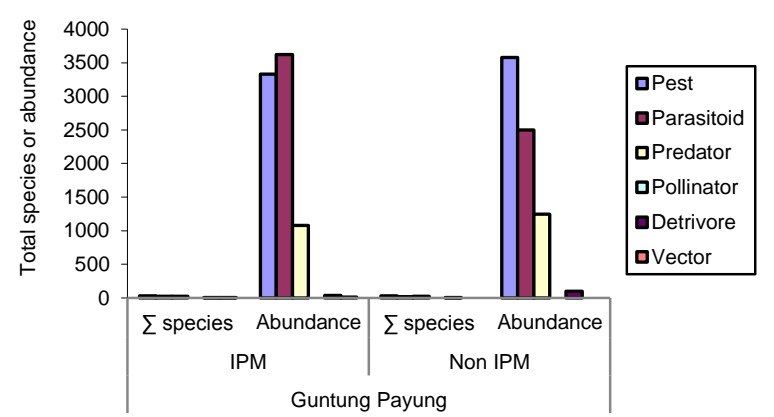

Figure 2. Histogram status, total of species and abundance of arthropods in Guntung Payung village

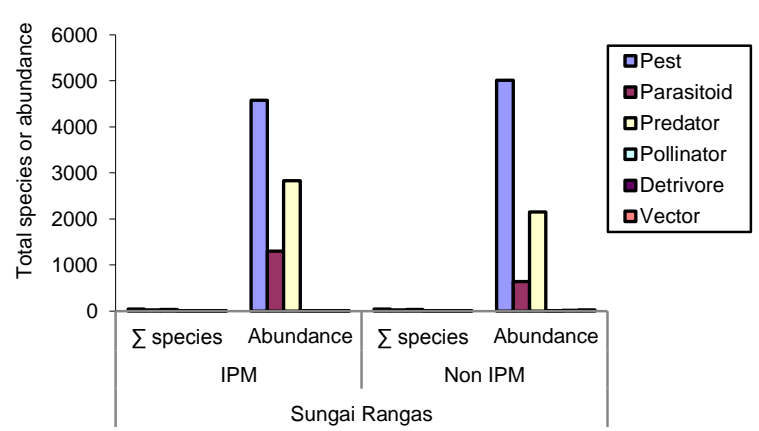

Figure3. Histogram status, total of species and abundance of arthropods in in Sungai Rangas village

Table 1. The sum, status, and abundance of arthropods in the IPM and non IPM paddy fields

\begin{tabular}{|c|c|c|c|c|c|c|c|c|c|c|c|c|}
\hline \multirow[t]{3}{*}{ Status } & \multicolumn{4}{|c|}{ Pasar Kamis } & \multicolumn{4}{|c|}{ Guntung Payung } & \multicolumn{4}{|c|}{ Sungai Rangas } \\
\hline & \multicolumn{2}{|l|}{ IPM } & \multicolumn{2}{|c|}{ Non IPM } & \multicolumn{2}{|c|}{ IPM } & \multicolumn{2}{|c|}{ Non IPM } & \multicolumn{2}{|c|}{ IPM } & \multicolumn{2}{|c|}{ Non IPM } \\
\hline & $\left(\sum \mathrm{Sp}\right)$ & Abd & $\left(\sum \mathrm{Sp}\right)$ & Abd & $\left(\sum \mathrm{Sp}\right)$ & Abd & $\left(\sum \mathrm{Sp}\right)$ & Abd & $\left(\sum \mathrm{Sp}\right)$ & Abd & $\left(\sum \mathrm{Sp}\right)$ & Abd \\
\hline Pest & 33 & 3178 & 27 & 2507 & 31 & 3328 & 29 & 3578 & 46 & 4579 & 44 & 5016 \\
\hline Parasitoid & 26 & 4172 & 20 & 3375 & 22 & 3623 & 19 & 2498 & 29 & 1298 & 23 & 643 \\
\hline Predator & 24 & 4676 & 20 & 2557 & 24 & 1076 & 24 & 1244 & 37 & 2828 & 35 & 2151 \\
\hline Pollinator & 0 & 0 & 0 & 0 & 0 & 0 & 0 & 0 & 1 & 2 & 1 & 3 \\
\hline Detrivore & 1 & 39 & 1 & 10 & 1 & 38 & 1 & 97 & 3 & 13 & 3 & 19 \\
\hline Vector & 1 & 13 & 1 & 12 & 1 & 14 & 0 & 0 & 1 & 9 & 1 & 28 \\
\hline Weed Natural Enemy & 0 & 0 & 0 & 0 & 0 & 0 & 0 & 0 & 1 & 150 & 1 & 130 \\
\hline Another & 3 & 153 & 3 & 65 & 6 & 498 & 0 & 0 & 0 & 0 & 0 & 0 \\
\hline Total & 88 & 12231 & 72 & 8526 & 85 & 8577 & 73 & 7417 & 118 & 8879 & 108 & 7990 \\
\hline
\end{tabular}

Note: $\sum$ Sp: Sum of species; Abd: abundance 
Table 2. Values of the arthropods H', e, R and IS in the IPM and non IPM paddy fields

\begin{tabular}{lllllll}
\hline & \multicolumn{2}{l}{ Pasar Kamis } & \multicolumn{2}{l}{ Guntung Payung } & \multicolumn{2}{l}{ Sungai Rangas } \\
Indeks & PHT & Non PHT & PHT & Non PHT & PHT & Non PHT \\
\hline $\mathrm{H}^{\prime}$ & 3.037 & 2.875 & 2.653 & 2.666 & 2.576 & 2.527 \\
$\mathrm{E}$ & 0.678 & 0.672 & 0.595 & 0.621 & 0.542 & 0.539 \\
$\mathrm{R}$ & 9.243 & 7.844 & 9.385 & 8.079 & 12.869 & 11.907 \\
$\mathrm{IS}$ & $77.50 \%$ & & $93.42 \%$ & & $78.78 \%$ & \\
\hline
\end{tabular}

The data was analyzed to determine the Species Diversity Index (H') using ShannonWiener Index (Zar, 1984), Species Richness Index (R), Species Evenness Index (e) according to Pielou (1984), and Sorenssen Species Similarity Index (IS) according to Suin (1989) [7,8,9].

The species diversity index (H'), Species Evenness Index (e), and Species Richness Index (R) values in the three IPM paddy field locations were relatively higher than in the non-IPM paddy fields, except for the Species Evenness Index (e) in Guntung Payung which was lesser. The Sorenssen Species Similarity Index (IS) in the three locations were, respectively, $77.5 \%$ in Pasar Kamis village, $93.42 \%$ in Guntung Payung village, and $78.76 \%$ in Sungai Rangas village. The complete data can be seen in Table 2, and a clearer illustration of the data is presented in the form of histogram as seen in Figure 4 and 5.

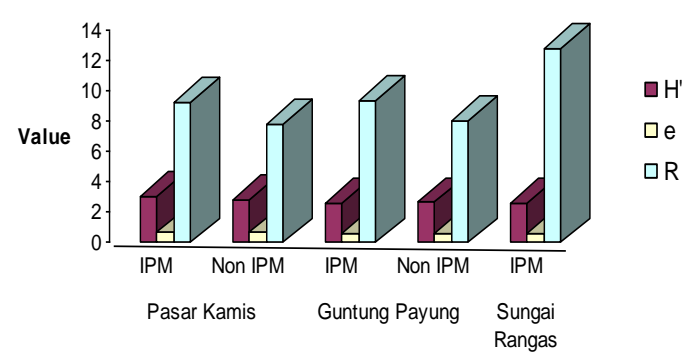

Figure 4. Histogram of the IPM and non IPM paddy fields $H^{\prime}$, e' and R index values in Pasar Kamis, Guntung Payung and Sungai Rangas village

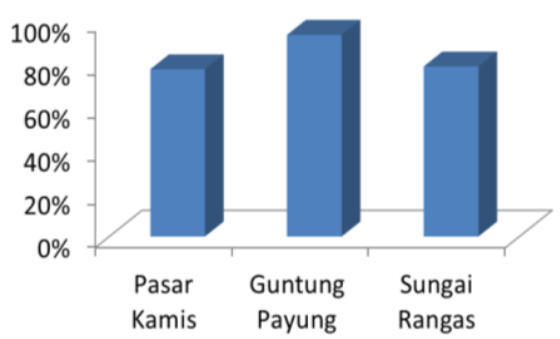

Figure 5. Histogram of the IPM and non IPM paddy fields IS index value in Pasar Kamis, Guntung Payung and Sungai Rangas village

The sum of arthropods species found in the IPM paddy fields is higher than in the non-IPM because the application of chemical substance, such as fertilizer and pesticide, in the IPM paddy fields is lower. In 2011, the IPM paddy fields only used chemical substance of herbicide kind in the planting preparation and carbofuran pesticide in the paddy nursery time. Meanwhile, beside using those two kinds of perticides, the non-IPM paddy fields also use chemical fertilizers (urea, SP 36, and $\mathrm{KCl}$ ) and insecticide to control the pests. According to Laba (2001), natural enemies, especially parasitoid and predator, are always present in annual paddy fields [10]. This condition is very suitable for pest abundance reduction because the organism might always present in all plant growth stadia. It is in line with Settle et al's (1996) statement that natural enemies and pest are always present in paddy field ecosystem[11]. However, the pesticide application to control pest will not only reduce the pest abundance but also cause ecosystem change because of the dead of the natural enemies such as parasitoid and predator [12].

Yaherwandi and Syam (2007) and Arifin et al. (1997) state that species biodiversity is one of the most important thing in the study of environmental change effects and how biodiversity influence the natural community stability[13,14]. The criteria used by Rahayu et al. (2006) explain that an organism species biodiversity is considered high when the value is $>3$, medium when the value is between 1-3, and low when the value is $<1[15]$. The Species Diversity Index (H') in Table 2 above which is included in high criterion is only the one found in the IPM paddy field in Pasar Kamis village, whereas the other locations have medium species diversity. The H' value of the IPM paddy field in Pasar Kamis village is high because the farmers only use very little amount of pesticide and other chemical substance when they apply the IPM concept (the writer's personal communication with the farmers in 2001). This result is in line with Laba's statement (2001) that the arthropods biodiversity before the IPM is done is lower than after the IPM is done. Similarly, Arifin et al. (1997) reports that species biodiversity in the 
paddy field ecosystem which does not apply pesticide is higher than in the paddy field ecosystem which applies pesticide) [14].

The Species Richness Index (R) and the Species Evenness Index (e) values are equal to the H' value. The Sorenssen Species Similarity (IS) value of $93.24 \%$ in Guntung Payung village is the highest. It is assumed that the cause of this fact is the very near location of the IPM paddy field and the non IPM paddy field which is only $\pm 50 \mathrm{~m}$. It causes a high mobility of the arthropods in the two paddy field ecosystems. According to Magurran (1988), the $\mathrm{R}$ value shows the sum of the species and the e value shows the abundance of the same species in the species found[16]. So, the higher the $\mathrm{R}$ value means the sum of the species found is also higher and the higher the e value means the abundance of the same species found is also higher. Margurran (1988) also states that the e value is between 0 to 1 where 1.0 means all species have the same abundance[16]. From Table 2 above, the $\mathrm{R}$ values in the three IPM paddy field locations are higher than in the nonIPM paddy fields. It is assumed that it happens because of the treatment given where the chemical substance application, such as fertilizer and pesticide, is relatively smaller so that the arthropods can develop better in the IPM paddy fields than in the non-IPM paddy fields. The e values of the IPM paddy fields in Pasar Kamis and Sungai Rangas villages are higher whereas it is on the contrary in Guntung Payung village. It is assumed that the IPM paddy field e value is higher because of the same reason that makes the $\mathrm{R}$ value higher in those three locations; and the $\mathrm{e}$ value of Guntung Payung village is different because the IPM and non IPM paddy field location is very near as mentioned above. The e value of all locations is $<1$, meaning that the abundance of all species are different [16].

\section{CONCLUSION}

From the study, it can be concluded that the arthropods species and abundance have more variations and develop better in the IPM paddy fields than in the non-IPM paddy fields, making the IPMS paddy field ecosystems more stable than the non- IPM paddy fields.

\section{ACKNOWLEDGMENTS}

We thank M. Indar Pramudi, SP who has spent his time helping us identifying and processing the data.

\section{REFERENCES}

1. Flint M L and Bosch R V (1990) Integrated Pest Management. Translated by Kartini Indah K and John Priyadi. Kanisius, Yogyakarta.

2. Oka I Ny (1995) Pengendalian Hama Terpadu dan Implementasinya di Indonesia. Gadjah Mada University Press. Yogyakarta.

3. Untung K ( 2003) Pengantar Pengendalian Hama Terpadu. Gadjah Mada University Press. Yogyakarta.

4. Untung K (2006) Pengantar Pengendalian Hama Terpadu. Gadjah Mada University Press. Yogyakarta.

5. Borror D J, De Long D M and Triplehorn C A (1991) An Introduction to The Study of Insects. Philadelphia, Saunders College Publishing.

6. Reissig WH, E A Heinrichs, JA Litsinger, K Moody, L Fiedler, T W Mew and A T Barrion (1986) Illustrated Guide to Integrated Pest Management in Rice in Tropical Asia. International Rice Research Institute Los Banos Lguna Philippines. Manila.

7. Zar J H (1984) Biostastical Analysis: Second Edition. Prentice Hall Inc. Englewood Cliffs. New Jersey 07632.

8. Pielou E C (1984) The Interpretation of Ecological Data. A Primer on Classification and Ordination. A Wiley Interscience Publication. John Wiley \& Sons. New York.

9. Suin (1989) Ekologi Hewan Tanah. Bumi Aksara. Jakarta.

10. Laba I W (2001) Keanekaragaman Hayati Artropoda dan Peranan Musuh Alami Hama Utama Padi pada Ekosistem Sawah. Post graduate program. Institut Pertanian Bogor. http://rudyct.com/PPS702-ipb/03112/iwlaba. htm. accessible 02 June 2010.

11. Settle WH, H Ariawan, E Tri Astuti, W Cahyono, A L Hakim, D Hidayana, A Sri Lestari and Pajarningsih (1996) Managing Tropical Rice Pest through Concervation of Generalist Natural Enemies and Alternative Prey. Ecology. 77(7): 1975-1988.

12. Sembel DT (2010) Pengendalian Hayati HamaHama Serangga Tropis dan Gulma. Andi Yogyakarta.

13. Yaherwandi and U Syam (2007) Keanekaragaman dan Biologi Reproduksi Parasitoid Telur Wereng Coklat Nillaparvata lugens Stal. (Homoptera: Delphacidae) pada Struktur Lanskap Pertanian Berbeda. Jurnal Akta Agrosia 10(1).

14. Arifin M, I B G Suryawan, B H Priyanto and A Alwi (1997) Diversitas Artropoda pada Berbagai Teknik Budidaya Padi Di Pemalang, Jawa Tengah. Penelitian Pertanian Puslitbangtan 15 (2): 5-12.

15. Rahayu S, A Setiawan, E A Husaeni and S Suyanto (2006) Pengendalian Hama Xylosandrus compactus pada Agroforestry Kopi Multi Strata Secara Hayati: Studi Kasus di Kecamatan 
Sumberjaya, Lampung Barat. Agrivita Jurnal Ilmu Pertanian. 28(3): 286-296

16. Magurran A E (1988) Ecological Diversity and Its Measurement. Princenton University Press Princenton. New Yersey. p 7- 37. 